\title{
Translating Collocations from English to Arabic among Iraqi EFL Learners
}

\author{
Aws Muayad Mahdi ${ }^{1,2} \&$ Mohamad Subakir Mohd Yasin ${ }^{1}$ \\ ${ }^{1}$ Universiti Kebangsaan Malaysia, Malaysia \\ ${ }^{2}$ MOHESR, University of Technology, Baghdad, Iraq \\ Correspondence: Aws Muayad Mahdi, pursuing an MA degree in English Language Studies at the School of \\ Language Studies and Linguistics, Universiti Kebangsaan Malaysia; a staff member in the Iraqi Ministry of \\ Higher Eduction at the University of Technology, Baghdad, Iraq. E-mail: aws_muayad@yahoo.com
}

Received: June 4, 2015 Accepted: June 29, 2015 Online Published: August 31, 2015

doi:10.5539/ells.v5n3p57 URL: http://dx.doi.org/10.5539/ells.v5n3p57

\begin{abstract}
This paper will thoroughly examine the notion of collocation and will analyse translations of English collocations into Arabic while detailing other related points. It will also incorporate a detailed explanation of the various types of collocations in English. A collocation is defined as a combination of two or more words that usually occur together in different language contexts. Although there have been many published literatures on collocation, there is limited examination of collocation in Iraq, and the specific problems faced by Iraqi EFL students translating English collocations into Arabic. This study examines the effect of mother tongue interference on the translation of English collocations into Arabic among Iraqi EFL students. The results reveal that $67 \%$ of the participants failed to achieve the pass mark, and only $33 \%$ achieved an acceptable level of understanding and translation. A detailed explanation of the results will be presented, as well as a conclusion and recommendation of this study.
\end{abstract}

Keywords: English collocations, English-Arabic translation, Iraqi English, Iraqi EFL learners, Iraqi students in Malaysia

\section{Introduction}

A collocation refers to the mix of two or more words that dependably appear together in common language. For example, a particular noun regularly occurs with the same adjective e.g. 'heavy metal' (وجبة دسمة), a verb frequently occurring with the same noun, e.g. 'catch the meaning' ("يفهم المعنى), a noun with a noun, e.g. some collocations can be translated (in a direct way very appropriately), as some collocations of the current test prove. After all, learners should be wary and reject to surrender from the first endeavor to the direct translation of any collocation. (Faris \& Sahu, 2013) Collocations appear to be significant in taking in a language in light of the fact that words are found out and utilized as a part of connection, and without knowing the fitting setting in which a word can be utilized, one can't make a claim that he or she has comprehended that word (Agah \& Soori, 2015). Because of the significance of collocations in language learning and practice, collocation word references in diverse languages have turn out to help learners over come difficulties that face them. The English language, in specific, has a gigantic abundance of word references that have dependably been discovered to be helpful and convenient for learners of English (Galal, 2015).

Baker (1992) states that collocations form an essential part of language, further explaining that they are a wonderful part of language and infuse in it an "invigorating soul". Collocations will exist at all times, be inescapable in any context, with no special case. Therefore, they are an essential part of translation. Al Kasimi (1993) states that leaners must truly understand collocations in Arabic in order to render the same magnificence that collocations add to the English language. This means that overlooking the translation of the English collocations in Arabic will result in poor, debilitated content in Arabic. On a basic level, settled expressions and representations of various types can be defined under the umbrella of collocations (Hedad, 1987). The majority of English and Arabic lexicons do not deal with the matter. English and Arabic lexicons manage phrases, however not with collocations. Additionally, learners cannot comprehend a collocation in the SL when he or she is not equipped for recalling its equivalent in the TL. 
The student's disappointment during such an attempt will typically reveal his selection of systems for lexical improvement, such as reduction, synonymy, reparation, summarising, and exchange. In these situations, unless the collocation example becomes part of the memory bank of the understudy, translator or learner, correspondence is destined to be limited. Generally, this disappointment is a direct result of the language instructor or educator's inclination to teach words exclusively rather than collectively. Therefore, syllabus planners should consider collocation, harnessing L2 learners' thoughtfulness regarding the methods in which collocational divergence occurs between L1 and L2. Collocations, rather than expressions, are not given due consideration by etymologists (Nofal, 2012).

\section{Statement of Problem}

Collocations consume a large portion of everyday language and add an additional source of flare and uniqueness to language, which increases the pleasure and fascination learners can obtain from adequate comprehension. However, translating collocations can prove to be an endless battle for L2 learners, with difficulties experienced in the correct selection of accompanying verbs, nouns and adjectives. The delivery of correct English lexical collocations has generally proved to be a problem for students learning English (Howarth, 1998; Hussain, 1998; Nesselhauf, 2003; Mahmoud, 2005; Falahi, 2012; Sadighi, 2013). Collocations are considered difficult for learners of a foreign language due to the unexpected instruments used. These problems can be credited to the similar qualities that both English and Arabic collocations show: low level of speculation, unpredictability, and variability. Interpretation of collocations can cause troubles for non-local speakers. Some collocations will be particular in the sense that they will be unexpected in terms of syntactic or semantic highlights. Additionally, "an interpreter can without much of a stretch misjudge a collocation in the source message because of obstruction from his/ her local language" (Baker, 2011, p. 59). Therefore, learners are obliged to be particularly sensitive to collocations and profoundly intrigued in discovering the equivalent collocation in Arabic, when it is accessible. Despite the fact that the translation of English collocations into Arabic by Arab learners has been examined, specific issues for Iraqi EFL learners have not been highlighted. Therefore, this study aims to address specific issues of translating English collocations into Arabic for Iraqi EFL learners at a Malaysian university, and how the translations influence the English translation into Arabic. This research endeavours to diagnose the challenges by examining the test results of an exam comprising fifteen sentences, each containing a collocation.

\section{Research Objectives}

These are the main objectives of this study:

1) To examine the difficulties encountered by Iraqi EFL students in translating English collocations into Arabic.

2) To investigate the effect of mother tongue interference on the translation of English collocations into Arabic among Iraqi EFL students.

\section{Research Questions}

Bearing in mind the objectives stated above, the following research questions are posted:

1) What are the difficulties encountered by Iraqi EFL students in translating English collocations into Arabic?

2) How does the mother tongue influence the translation of English collocations into Arabic among Iraqi EFL students?

\section{Significance of the Study}

The significance of this paper is that it will further add to the body of knowledge of linguistic investigation. It will explore the nature of collocation in the English language as well as examine some of the related and interlocking fields of study surrounding collocation. Research up until this point in time is limited, and there are gaps in knowledge. Therefore, it is hoped that this study will contribute new information to this field of study, as well as confirm and further enhance previous research. It will present a clear definition of collocation and a thorough analysis and description of its uses in English study. A study involving the use of English by native Arabic speakers will be introduced as a means of further explaining the theories and testing the research evaluation.

\section{The Concept of Collocation}

A collocation is a lexical connection and is not subject to standards, more so to inclinations. Firth (1968) uniquely defines it as "the organisation that words stay with" or "actual words in on-going" (p. 182). Firth (1968) adequately joined the significance of this "level of signifying" and proposed the set-up of different collocational levels of investigating dialect, notwithstanding the situational, syntactic, phonological and different levels. 
Halliday (1966) framed the idea of collocation, yet did not include Firth's concept of independent levels of collocation. In Halliday's (1966) hypothesis, syntax and lexis are two particular, however interrelated, levels of semantic structure, with each level possessing its own unique syntagmatic and paradigmatic relations, such as structures and framework in punctuation, collocations and groups in lexis. Lyons (1966) argues that a complete theory of semantics cannot be achieved as the application of Firth's contextual theory of meaning and the analysis of patterns of co-occurrence without giving consideration to their semantic compatibility will not sufficient. Mitchell (1965, p. 143) further delivers on this point, and offers an extended definition of collocation. He states that collocation is an association of the roots or the potential lexical meaning of words rather than the actual words themselves. He further states that "a linguistic item or class of items is meaningful not because of inherent properties of its own, but because of the contrastive or differential relationship it develops with other items or classes." Further to this, Mitchell (1965) also details the continuous nature of collocations. He states that they cannot run across sentence boundaries, which further stresses the continuously syntagmatic nature of Firthin, or "lexical" approach to linguistic analysis.

\subsection{Types of Collocations}

Appropriate identification of research participants is critical to the science and practice of psychology, particularly for generalizing the findings, making comparisons across replications, and using the evidence in research syntheses and secondary data analyses. If humans participated in the study, report the eligibility and exclusion criteria, including any restrictions based on demographic characteristics. Collocations can be categorised into several categories. This study mostly focuses on the recurrent collocations, and the ones that most interest the students being tested. Aziz (1982) states that collocations are easier to follow and understood when grammatical descriptions are adopted, and hence the translation to Arabic is easier. These examples are outlined in the following points:

\section{Adjective + noun collocation:}

1- "Wrong claim" (ادعاء خاطئ)

2- "Big mistakes" (أخطاء كبيرة)

In most cases, these collocations can be translated into identical Arabic collocations (noun + adjective).

2. Verb + noun collocations:

1- "Seize opportunity" (ينتهز الفرصة)

2- "Offers gift" ("يقدم هدية)

The main difficulty in this example is matching a certain verb to a particular noun in Arabic (as the examples show).

3. Noun + noun collocations:

1- "Food dish" (صحن الطعام)

2- "Garden House" (حديقة المنزل)

Aziz (1982, p. 93) states that the collocations will usually have an Arabic equivalent. However, they may use a different grammatical structure. The two most frequently used structures in the Arabic language are: (i) noun + adjective (status quo) and (ii) noun + noun (as seen in several examples).

4. Noun + noun (the of genitive) collocations:

1- "Loss of money" (فقدان النقود)

2- "the heart of the matter" ( جوهر الاثشياء)

Mahmoud (1994, p. 43) views these collocations as translatable into equivalent Arabic collocations of identical grammatical structure, or "of genitive."

5. Noun + and + (addition) collocation:

1- "Good and bad" (الجيد والسئ) (الجئ)

2- "Rights and duties" (الحقوق والو اجبات)

These collocations are generally easy to translate and translatable into "noun + and + noun" collocations in the Arabic language (Adnan, 1996, p. 73). 
6. Adjective + adjective collocations:

1- "hale and hearty" (بصحة جيدة)

2- “wealthy and well” (بصحة وعافية)

The problem with translating such regular collocations into Arabic is that the syntactic structure is diverse and very unusual (Usama, 1998, p. 104).

7. Adverb + adverb collocations:

1- "wholly and heartedly" (بالتمام و الكمال)

2- "willy and nilly" (رغما انفه)

These two Arabic translations are collocations. However, they have diverse linguistic structures. They are syntactically diverse from the English collocations (Abu Risha, 1986, p. 77).

8. Noun + verb collocations (names of sounds):

1- "Crying Baby" (بكاء الطفل)

2- "Bird song" (تغريد الطيور)

Benson (1985, p. 177) explains that these collocations should not be difficult to translate into collocations in Arabic. The main issue for learners is the requirement to have a capacity to perceive the sound of the example required in Arabic.

\section{Prepositional Collocations}

Noun + preposition collocation:

1 - "play on (words)" التلاعب بالالفاظ))

2- "a claim for" (ادعاء)

Faruqi (1994) warns that language students must be aware of the direct translation of the preposition.

Preposition + noun collocations:

1- "by accident" (بمحض الصدفة)

2- "under the patronage (of)" (تحت رعاية)

Adjective + preposition collocations:

1- “Upset at" (هنز عج من)

2- "Fugitive at" (هن من (ن) (هن)

Verb + preposition collocations (prepositional verbs:

1- "need to" (يحتاج الى)

2- "wait for" (ينتظر لـ (بن)

10. Collocations of Similes

(as...as constructions)

1- "as beautiful as a lark"/ "as pretty as a picture" (الحلى من الصورة)

2- "as White as a snow" (ابيض من الثلج)

11- Parts of countable nouns' collocations, e.g.:

1- “a bouquet of flowers" (باقة من الورود)

2- "a crowd of people" (حشد من الناس)

Parts of uncountable nouns' collocations:

1- "an act of violence" (عل عنيف)

2- "Piece of bread" (قطعة خبز)

These collocations are used to allude to parts of a noun that cannot be included in English. There are also comparative collocations in Arabic. However, there are a few nouns that are uncountable in English, yet countable in Arabic: 


\section{1 (اعمال............ (عمل)}

2- (اخبار ................. (أعبر)

They should therefore not be translatable into collocations, but into single words only, like "a bit (piece) of information" and "a bit (piece) of advice." (Heil, 1990, p. 74).

\subsection{Collocations and Translation}

Collocation refers to the lexical relationship between words. It is a phenomenon that is unique to language learning and which the nature differs slightly from one language to another. Cultural differences can also influence the nature of lexical relationships and make the study of collocations complex in nature. Because of this, translating collocations has been proven to be an area of great difficulty. There are several problems when translating collocations from one language to another. This is due to the discrepancies in the cultural and linguistic structures between the SL and TL, as well as different systems, conventions and lifestyles which add variety and colloquial inference to the nature of collocations (Al-Rawi, 1994). Accurate translations rely on the concept of understanding the exact TL equivalents. Catford (1965, p. 50) states that "translation equivalence occurs when an SL and TL text or item are relatable (or at least some of) the same features of substance". That is, translating collocations can become inaccurate or difficult when a translator fails to identify the equivalent TL lexical item, which correlates to the lexical item within the SL, which can ultimately result in unnatural expressions (Al-Rawi, 1994)

\section{Theoretical Framework of the Study}

It has been suggested that meaning may not be restricted to single lexical units, and that collation, or lexical meaning, is part of the five dimensions of meaning, including lexical, morphological, phonetic, semantic and syntactic (Firth, 1935, 1957, p. 11). Firth (1957) describes collocation as "the company a word keeps." Stubbs (2002, p. 225) offers a similar definition, stating that collocation is the "semantic relations between the node and collocates." Stubbs (2001b, p. 14) further goes on to state that collocation is a basic unit of language, and that "combinations of words in phrases are... a good candidate for the basic unit of language in use." It is evident from literature that there is more focus on lexical, instead of grammatical, collocation (Grimm, 2009; Sinclair, 1991; and Sinclair \& Jones, 1974). This study will explore the aspects of meaning and the ability of respondents to use and understand the concepts. Palmer $(1933,1938)$ made note of the significance of collocation in verbal communication, explaining that rather than focusing on the importance of grammar in language learning, each word may be composed of its own grammar. To support this, Favretti $(2008$, p. 92) states the "polysemy of the word is disambiguated by the representation of its collocates." Many authors agree that a translator will often be caught out by incorrect and inappropriate use of collocations, rather than their grammar and vocabulary, which may often be more developed or wider than a native speaker (Farghal \& Obiedat, 1995); Al-Shormani \& Al-Sohbani (2012).

\section{Method}

\subsection{Participants}

The participants of the research were twenty male Iraqi EFL students at a university in Malaysia. They are aged between 23 and 30 and studied English in primary and secondary schools and during their Bachelor degree. The students are now completing a Master degree at this university. It would therefore be assumed that a high level of English awareness and understanding would be obtained by the students, and that they should have a strong understanding of how to translate collocations from English to Arabic. All participants were native Arabic speakers, with English being learned as a secondary language.

\subsection{Procedures}

Twenty male Iraqi EFL students from a university in Malaysia were selected to participate in the study. Prior to the commencement of the test, the researchers read the test instructions loudly and clearly to ensure all participants were aware of the nature and intention of the testing. Students were asked to translate fifteen English sentences into Arabic in a thirty-minute timeframe. Students were asked to write their answers on a sheet of A4 paper. The use of reference dictionaries was strictly forbidden. Responses were collected in preparation for analysis. In the first state of analysis, the responses were checked for accuracy with assistance from a language professor from Baghdad University, who had taught English for more than twenty years. The emphasis was on analysing the translation of collocations within the sentences. The final result of each sentence was taken from the deduction of the average marks by two separate tests. Analytically, the method used for analysis was a qualitative one. The results of the test were then examined and the reasons for the common misuse of collocations, as well as weaknesses of the respondents, were analysed. 


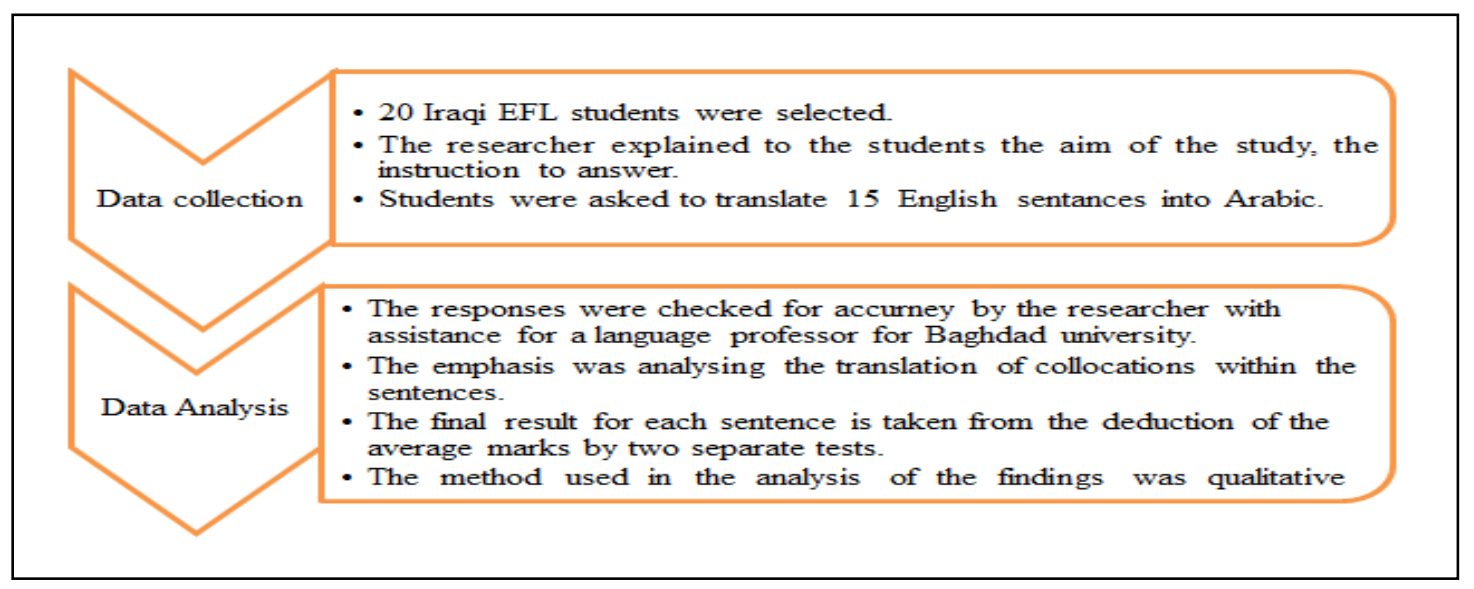

Figure 1. Research procedures

\subsection{Instrument}

The test was made up of fifteen separate sentences, each containing at least one collocation. The selected collocations were derived from Benson (1985), Mahmoud (1994) and Usama (1998). The researchers have chosen these references due to prove its success in giving the results of high-value and necessary were used as a source of data for many studies like the one conducted by Faris and Sahu (2013). In addition, these sources content of importance to achieve the goal of this study, which is investigating the phenomenon of translating English collocations into Arabic. The instructions given to the students were as follows: a). to translate each of the following sentences into Arabic, and b). to pay close attention to the translation of the underlined words.

1- He gave me a warm reception.

2- Today is a good day.

3- We must seize the opportunity when it comes.

4- English Literature is an essay bank.

5- It is hard to learn about the hour of decision.

6- The contract has terms and conditions.

7- She feels well and good.

8- I will stand with you secretly and publicly.

9- My girl gets alarmed by the door's creak.

10- Our ignorance of polling could be backfired.

11- I decided to attend Medicine College on my father's advice.

12- We are foreign to his ideals.

13- People almost protest against the unfamiliar.

14- She is as pretty as a picture.

15- In my dreams I saw a school of whales. 


\section{Result and Discussion}

Table 1. Results and Discussion

\begin{tabular}{|c|c|c|}
\hline No. & The sentences & Discussion \\
\hline 1 & $\begin{array}{l}\text { He gave me a warm } \\
\text { reception. }\end{array}$ & 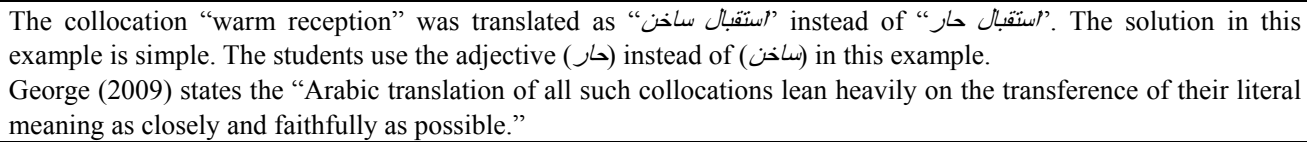 \\
\hline 2 & Today is a good day. & $\begin{array}{l}\text { A second example can be seen in the collocation "a good day." Generally, the correct grammatical structure used in } \\
\text { this collocation in Arabic is (adjective + noun); however, they have not used the correct Arabic equivalent } \\
\text { collocation. In a lot of cases, the students used "بوم werather which is a more appropriate word } \\
\text { choice. Collocations like this often prove difficult for students translating into Arabic, as it is often difficult to find } \\
\text { an English equivalent adjective. }\end{array}$ \\
\hline 3 & $\begin{array}{l}\text { We must seize the } \\
\text { opportunity when it } \\
\text { comes. }\end{array}$ & 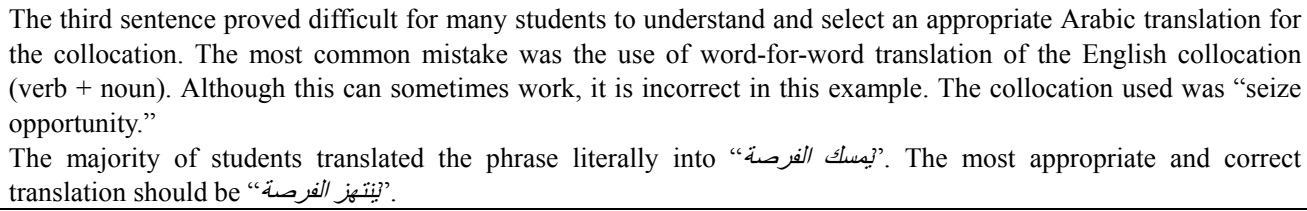 \\
\hline 4 & $\begin{array}{l}\text { English Literature is an } \\
\text { essay bank. }\end{array}$ & 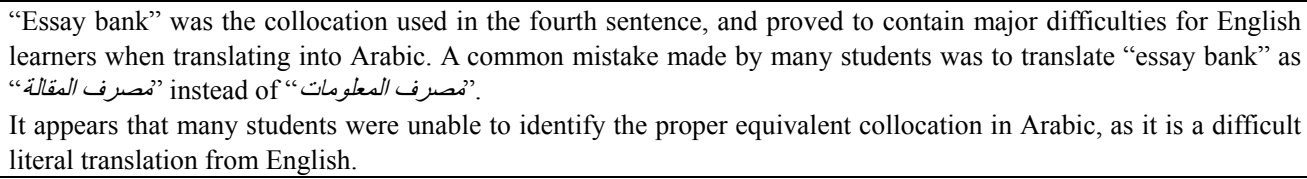 \\
\hline 5 & $\begin{array}{l}\text { It is hard to learn about } \\
\text { the hour of decision. }\end{array}$ & $\begin{array}{l}\text { Sentence five contained the example "the hour of decision." } \\
\text { Most participants translated the text as "ساعة القرار" when it should have been translated as "ساعة الحسم". }\end{array}$ \\
\hline 6 & $\begin{array}{l}\text { The contract has terms } \\
\text { and conditions. }\end{array}$ & $\begin{array}{l}\text { In sentence six, "terms and conditions" Such a collocation shows that there is an equivalent collocation the students } \\
\text { should insist on finding it. } \\
\text { There are literal translations, and at the same time students should do their best to understand the English } \\
\text { collocation properly. }\end{array}$ \\
\hline 7 & $\begin{array}{l}\text { She feels well and } \\
\text { good. }\end{array}$ & $\begin{array}{l}\text { The seventh sentence proved a common difficulty amongst most of the participants. It contained the phrase "well } \\
\text { and good," which has a different grammatical structure in Arabic i.e. it should be translated into "preposition + } \\
\text { noun + noun." } \\
\text { It should be translated as "على خبر مابر/م". However, most participants used "نها تشعر جبية". }\end{array}$ \\
\hline 8 & $\begin{array}{l}\text { I will stand with you } \\
\text { secretly and publicly. }\end{array}$ & 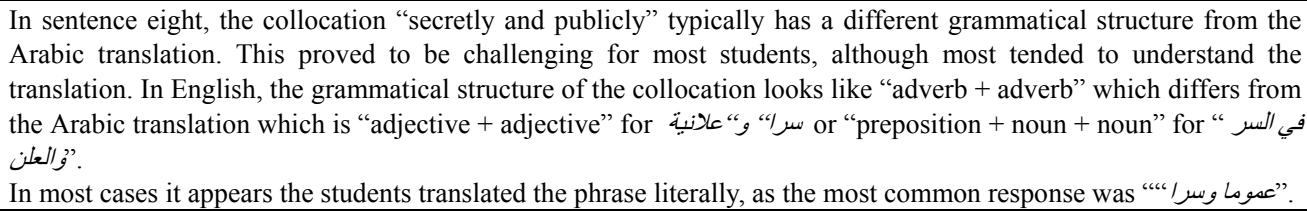 \\
\hline 9 & $\begin{array}{l}\text { My girl gets alarmed by } \\
\text { the door's creak. }\end{array}$ & $\begin{array}{l}\text { Sentence nine, which contained the collocation "door creak," posed a problem for most students as they did not } \\
\text { know the name of a door's sound in the target language. The grammatical structure of the collocation in Arabic } \\
\text { should be "noun + noun," not "noun + verb" as it is in English. }\end{array}$ \\
\hline 10 & $\begin{array}{l}\text { Our ignorance } \quad \text { of } \\
\text { polling could be } \\
\text { backfired. }\end{array}$ & 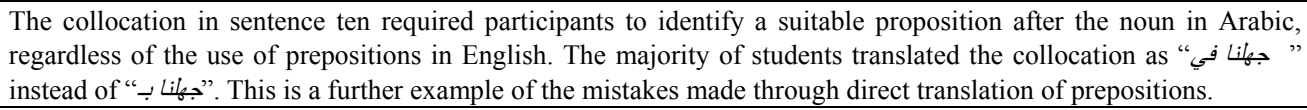 \\
\hline 11 & $\begin{array}{l}\text { I decided to attend } \\
\text { Medicine College on } \\
\text { my father's advice. }\end{array}$ & 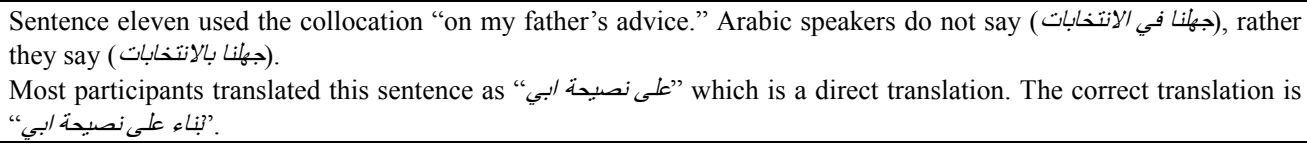 \\
\hline 12 & $\begin{array}{l}\text { We are foreign to his } \\
\text { ideals. }\end{array}$ & $\begin{array}{l}\text { In sentence twelve, participants were required to understand collocation with a fixed expression in Arabic. The most } \\
\text { common mistake was due to direct translation. The meaning of the preposition caused much confusion amongst the } \\
\text { students with this specific collocation despite the grammatical construction of the collocation being the same in } \\
\text { English and Arabic (adjective + preposition). }\end{array}$ \\
\hline 13 & $\begin{array}{l}\text { People almost protest } \\
\text { against the unfamiliar. }\end{array}$ & $\begin{array}{l}\text { Sentence thirteen also caused problems due to direct literal translation. The collocation "protest against" was } \\
\text { translated by many participants as "بحتج ضد". A collocation such as this can be a fixed phrase with a fixed meaning. }\end{array}$ \\
\hline 14 & $\begin{array}{l}\text { She is as pretty as a } \\
\text { picture. }\end{array}$ & $\begin{array}{l}\text { There appeared to be cultural differences which caused problems for all participants in sentence fourteen as the } \\
\text { collocation cannot by changed or amended in the middle. The equivalent in Arabic is usually a comparative } \\
\text { grammatical form of exaggerations (i.e. "better than") as opposed to an equal form (i.e. "something = something"). } \\
\text { Every participant translated the collocation as (كالصورة جمبل) when it should be translated as } \\
\text { (الصورة). Again, participants must be aware of the dangers of direct translation. }\end{array}$ \\
\hline 15 & $\begin{array}{l}\text { In my dreams I saw a } \\
\text { school of whales. }\end{array}$ & 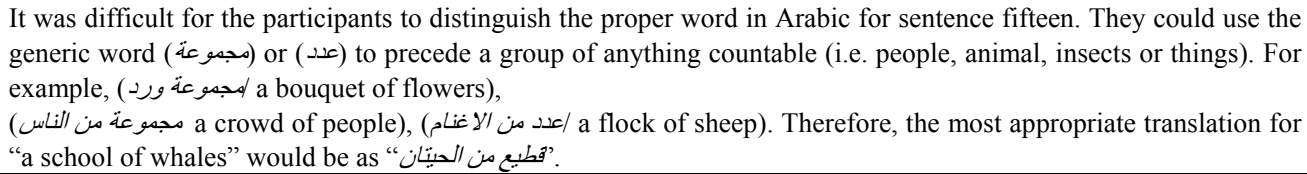 \\
\hline
\end{tabular}




\section{Conclusion}

English learners could easily understand the selected collocations, but they had difficulties to correctly translated them into Arabic. Both Arabic and English use collocations, where words tend to be placed together within a lexical relationship, which is highly influenced and restricted by the language speakers' tendency as well as their culture. In both languages, collocations can be classified, depending on the range of their co-occurrence, into open collocations, where an item has a wide range of collocates. Correctly producing collocations depends a lot on cultural knowledge, more so than linguistics and semantic knowledge. The results show that Iraqi EFL learners were incompetent in collation pattering and they tended to associate words inappropriately. This is evident in the fact that $67 \%$ of participants failed to achieve the pass mark, and only $33 \%$ showed an acceptable level of understanding and translation. In most cases, errors were made due to the tendency to literally translate the text. Collocations are very important in truly understanding a language as they reveal the naturalness and cohesiveness of the text. Teachers of English as a foreign language in Iraq should pay great attention to collocations during the translation phase.

\section{References}

Ackermann, K., \& Chen, Y. H. (2013). Developing the Academic Collocation List (ACL)-A corpus-driven and expert-judged approach. Journal of English for Academic Purposes, 12(4). http://dx.doi.org/10.1016/j.jeap.2013.08.002

Agah, M., \& Soori, A. (2015). Comparative Study of Collocation among the Languages. Language in India, 15(1).

Al- Kasimi, M. (1993). Varieties of English Simplified. Malta: Elga.

Al Rawi, S. (1994). Collocations in Arabic. Unpublished PHD thesis. Baghdad: Baghdad University.

Al-Shormani, M. Q., \& Al-Sohbani, Y. A. (2012). Semantic Errors Committed by Yemeni University Learners: Classifications and Sources. International Journal of English Linguistics, 2(6). http://dx.doi.org/10.5539/ijel.v2n6p120

Aziz, Y. Y. (1982). Cultural Problems of English-Arabic Translation. Babel: International Journal of Translation, 28(1).

Baker, M. (1992). In Other Words: A Course book on Translation. London and New York: Routledge. http://dx.doi.org/10.4324/9780203327579

Baker, M. (2011). In Other Words: A Course book on Translation. New York: Routledge.

Benson, M. (1985). Collocations and idioms. Dictionaries, lexicography and language learning. New York: CUP.

Catford, J. C. (1965). A linguistic theory of translation (Vol. 74). London: Oxford University Press.

Falahi, M., \& Moinzadeh, A. (2012). Effects of Receptive and Productive Tasks on Iranian EFL Students' Learning of Verb-noun Collocations. Journal of Language Teaching and Research, 3(5). http://dx.doi.org/10.4304/j1tr.3.5.953-960

Faris, A. A. H., \& Sahu, R. A. (2013). The Translation of English Collocations into Arabic: Problems and Solutions. Journal of the College of Arts. University of Basra.

Faruqi, N. H. (1994). Cross Cultural Link in Translation. Beirut: Librairie du Liban.

Firth, J. R. (1968). Selected papers of JR Firth, 1952-59. Bloomington: Indiana University Press.

Galal, M. M. (2015). Lost in Collocation: When Arabic Collocation Dictionaries Lack Collocations. English Language and Literature Studies, 5(2). http://dx.doi.org/10.5539/ells.v5n2p18

Gorges, D. T. (2009). The Translation of Arabic Collocation into E Based vs. Dictionary- Free Measured Knowledge. Retrieved from www.esl.fis.edu

Halliday, M. A. (1966). Lexis as a linguistic level. In memory of JR Firth. Bloomington: Indiana University Press.

Hedad, E. W. (1987). Fixed Expressions in English. Egypt: Dar Al- Marifa.

Heil, M. (1990). Collocations and Translations in Arabic. Tanger: Morocco Press.

Howarth, P. (1998). Phraseology and second language proficiency. Applied linguistics, 19(1). http://dx.doi.org/10.1093/applin/19.1.24 
Hussein, R. F. (1998). Collocations revisited. Journal of King Saud University, Saudi Arabia.

Lyons, J. (1968). Introduction to theoretical linguistics. London: Cambridge University Press. http://dx.doi.org/10.1017/CBO9781139165570

Mahmoud, A. (2005). Collocation errors made by Arab learners of English. Asian EFL Journal, 5(2).

Mahmoud, F. (1994). Problems of Collocations Translations. Rabat: Maktab Tanseeq Al- Tareeb.

Mitchell, T. F. (1975). Linguistic "Going-on": Collocations and Other Lexical Matters Arising on the Syntagamatic Record. In J. R. Firth (Ed.), Principles of Firthian Linguistics. London: Longman.

Nesselhauf, N. (2003). The use of collocations by advanced learners of English and some implications for teaching. Applied linguistics, 24(2). http://dx.doi.org/10.1093/applin/24.2.223

Nofal, K. H. (2012). Collocations in English and Arabic: A Comparative Study. English Language and Literature Studies, 2(3).

Sadighi, S., \& Sahragard, R. (2013). The Effect of Lexical Collocational Density on the Iranian EFL Learners' Reading Comprehension. Journal of Teaching Language Skills, 5(1).

Usama, H. (1998). The Translation of Collocating Vocabulary Items. Beirut: Dar Ash-sham Lil- Turath.

\section{Copyrights}

Copyright for this article is retained by the author(s), with first publication rights granted to the journal.

This is an open-access article distributed under the terms and conditions of the Creative Commons Attribution license (http://creativecommons.org/licenses/by/3.0/). 